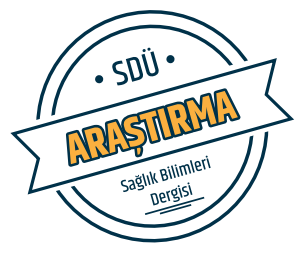

\title{
Yaşa Bağlı Makular Dejenerasyonu Olan Hastaların Beslenme Durumlarının Değerlendirilmesi
}

\section{Assessment of Nutritional Status of Patients with Age-Related Macular Degeneration}

\author{
Mustafa Özgür ${ }^{1}$, Aslı Uçar ${ }^{1}$ \\ ${ }^{1}$ Ankara Üniversitesi Sağlık Bilimleri Enstitüsü, Beslenme ve Diyetetik AD, Ankara, Türkiye.
}

\section{Özet}

Amaç: $\mathrm{Bu}$ araştırmada yaşa bağlı makular dejenerasyonu olan bireylerin beslenme durumunun değerlendirilmesi amaçlanmıştır.

Materyal-Metot: Araştırma, Göz Hastanesine başvuran ve herhangi bir göz hastalığ olan bireyler üzerinde yapılmıştır. Çalışma Yaşa Bağlı Makular Dejenerasyonu(YBMD) olan (erkek:46; kadın:29) ve olmayan (erkek:48; kadın:26) toplam 151 hasta ile yürütülmüştür.

Bulgular: Çalışmaya katılan bireylerin \%62,3'ü erkek, \%37,7'si kadındır Çalışmaya katılan bireylerden YBMD'si olanların \%26,7'si, kontrol grubunun \%30,3'ü yetersiz enerji; YBMD'si olanların \%14,7'si, kontrol grubunun \%15,8'i yetersiz karbonhidrat; YBMD'si olanların \%30,7'si, kontrol grubunun \%28,9'u yetersiz protein ve YBMD'si olanların $\% 64,0$ 'ü, kontrol grubunun $\% 53,9$ 'u yetersiz miktarda posa almaktadır.

Sonuç: Sonuç olarak bazı makro ve mikro besin ögesi alımları ile hastalığın seyri arasında ilişki bulunmuştur. Bireylerin çoğunluğunun yaşına uygun enerji, karbonhidrat ve protein aldıkları, posa alımlarının ise önerilerin altında olduğu saptanmıştır. Makular dejenerasyonu olan hastalarda, hastalığın ilerleyişinin durması veya azalması için antioksidan vitamin içeriği yüksek sebze ve meyve tüketiminin arttırılması gerektiği düşünülmektedir.

Anahtar kelimeler: Beslenme durumu, makular dejenerasyon, yaşlı beslenmesi.

\begin{abstract}
Objective: In this study, it was aimed to evaluate nutritional status of individuals with age-related macular degeneration.
\end{abstract}

Material-Method: The study was conducted on individuals referred to the University of ............ Eye Hospital and had any eye disease. The study was conducted with a total of 151 patients with Age Related Macular Degeneration (ARMD) (male:46; female:29) and other eye diseases (male:48; female:26).

Results: Sixty two point three percent of the individuals participating in the study were male, $37,7 \%$ were female. $26.7 \%$ of those participating in the study and $30.3 \%$ of the control group had inadequate energy; $14.7 \%$ of those with AMD and $15.8 \%$ of the control group had inadequate carbohydrate; $28.9 \%$ of the control group had an inadequate amount of protein, and $64.0 \%$ of the control group and $53.9 \%$ of the control group were inadequate.

Conclusions: As a result, some macro and micro nutrient intakes were correlated with the course of the disease. It has been determined that most of individuals receive energy, carbohydrates and protein suitable for their age, and that the fiber intake is below the recommendations. In patients with macular degeneration, antioxidant vitamin content, high vegetable and fruit consumption, should be increased to prevent or slow the progression of the disease.

Keywords: Nutritional assessment, macular degeneration, elderly nutrition.

\section{Giriş}

Yaşlanma, organizmanın molekül, hücre, doku, organ ve sistemlerinde, zamanın ilerlemesi sonucu ortaya çıkan, geri dönüşümsüz yapısal ve fonksiyonel değişiklerin tümü olarak adlandırılmaktadır (1). Dünya Sağlık Örgütü (DSÖ) 65 yaş üstü bireyleri yaşlı birey olarak kabul etmektedir (2).

Yaşlanmaya başlayan bir toplum, kardiyovasküler hastalıklar, hipertansiyon, insüline bağımlı diyabet hastalığı gibi kronik hastalıklara, osteoporoz ve sarkopeni gibi fiziksel engellere, parkinson ve alzheimer gibi zihinsel hastalıklara ve göz hastalıklarına daha sık yakalanmaktadır (3).
Yaşlı bireylerin yaşam kalitesini etkileyen ve sosyal izolasyona maruz kalmalarına neden olan hastalıklardan biri de sarı nokta hastalığı olarak bilinen yaşa bağlı gelişen makular dejenerasyon (YBMD)'dur. $\mathrm{Bu}$ durum görme bozukluğu ile ilişkili olup, yaşlı bireylerde ilerleyici, bilateral körlüğün önde gelen nedenlerinden biridir (4-5) ve ilk kez 1885 yılında keşfedilmiştir (6). Hastalığın temelinde yaşlılık olmasına rağmen, bireyin beslenme örüntüsünün de hastalığın gelişmesinde anahtar rol oynadığı ortaya konmuştur (7-8).

Hastalık temel olarak retinanın oksijenlenmesini ve beslenmesini sağlayan koryo kapillarisi, bruch membranı 
ve retina pigment epitelini etkilemektedir. Fakat görme kaybının tipik olarak eş zamanlı sıvı birikimi, kanama, lipit eksudasyonu ve fibrozis ile birlikte gelişen, atrofi veya koroid neovaskülarizasyonun neden olduğu fotoreseptör disfonksiyonuna bağlı olduğu düşünülmektedir(5). Hastalığın erken döneminde retinada klinik olarak gözlemlenebilen sarı noktalar (drusen) ve hiper - hipopigmentasyonlu pigmenter anormallikler gelişmektedir (9).

Yapılan çalışmalarda YBMD tanımlaması ve sınıflamasında farklı yöntemlerin kullanılması, yaş, sosyodemografik ve genetik farklılıklar nedeniyle hastalığın prevalansı farklılık göstermektedir (10). Hastalığın prevalansı 19881994 yıllarında yapılan The National Health and Nutriton Examination Survey'e (NHANES- Ulusal Sağlık ve Beslenme İnceleme Taraması) göre \%9,4 olarak saptanmıştır (11). Aynı standartları kullanarak YBMD prevalansını saptamak için 1995-1997 yıllarında yapılan Blue Mountain Çalışması, Beaver Dam Çalışması ve Rotterdam Çalışması'nda ise prevalansı sırasıly $\% 1,9, \% 1,2$ ve $\% 1,7$ olarak saptanmıştır (12-14). Tekrarı yapılan Beaver Dam çalışmasında nüfusun hızla yaşlanmasından dolayı YBMD prevalansı 55 yaş üstü bireyler için \%3,4 olarak rapor edilmiş ve yaş ilerledikçe bu oranın her 5 yaşta \% 1,2 artığ 1 bildirilmiştir (15).

Hastalığın temel risk faktörü yaş olsa da genetik faktörler (16), beyaz 1rk (17), cinsiyet farklılığı (15), sigara ve alkol kullanma durumu (13), kardiyovasküler faktörler ve diyabet gibi kronik hastalıklar ve iris rengi gibi göze ilişkin faktörler (18) de YBMD için risk faktörü olduğu çalışmalarda gösterilmiştir (19-22).

Yaş, cinsiyet ve genetik faktörler göz ardı edilse bile değiştirilebilir risk faktörleri YBMD olan bireylerin yaşam kalitesini düşürmektedir. Bu durumdaki bireylerde özellikle beslenme düzeninin etkisi göz ardı edilmemelidir. Diğer çevresel risk faktörlerinin yanında kan-oküler bariyeri ve retinal pigment epiteli üzerine etki eden makro ve mikro besin ögeleri gibi diyetsel faktörler bulunmaktadır (23). Makro ve mikrobesin ögeleri ile antioksidan vitamin ve minerallerin diyette yetersiz olmasının hastalık için risk faktörü olduğu düşünülmektedir. Özellikle lutein, zeaksantin, A, C, E vitaminleri ile antioksidan etkileri bilinen çinko, bakır ve selenyum minerallerinin hastalıkla ilişkisi incelenmiştir (24). Ancak karbonhidrat ve yağların, B grubu vitaminler ile D vitamininin, omega-3 ve omega-6 yağ asitlerinin, antioksidan etkileri bilinen flavonoidlerin ve diğer diyetsel faktörlerin etkisi de göz ardı edilmemelidir (5,25-27).

$\mathrm{Bu}$ araştırmada yaşa bağlı makular dejenerasyonu olan bireylerin beslenme durumunun değerlendirilmesi amaçlanmıştır.

\section{Materyal-Method}

\section{Araştırmanın Yeri, Zamanı ve Örneklem Seçimi}

Araştırma evreni, ..................... Göz Hastanesi'ne başvuran ve herhangi bir göz hastalığına sahip olan bireylerdir. Çalışmaya 2 aylık süre boyunca toplam 202 kişi gelmiştir. YBMD'si olan hastalar için en az 1 yıl önce tanı almış olması, kontrol grubu için YBMD dışında herhangi bir göz hastalığı tanısı almış olması, hem YBMD hem de kontrol grubu için 65 yaş ve üzeri hastalar olması, bilişsel işlevlerinde bozukluk olmaması çalışmaya dahil edilme kriterleri olarak seçilmiştir. Çalışmaya katılmayı kabul eden 202 kişiden 51'i çalışmaya dahil olma kriterlerini karşılamamaktadır. $\mathrm{Bu}$ nedenle, çalışma 75 YBMD (46 erkek; 29 kadın), 76 kontrol grubu (48 erkek; 28 kadın) olmak üzere 151 kişi ile tamamlanmıştır. Katılımcılar gelişigüzel örnekleme yöntemi ile seçilmiştir

Gerekli izinler ve etik kurul onayı alınmıştır.

\subsection{Verilerin Toplanması ve Değerlendirilmesi}

Araştırma verileri, araştırmacı tarafından anket formu ile yüz yüze görüşme tekniği kullanılarak toplanmıştır. Soruların anlaşılabilirliği öncelikle 30 kişi ile test edildikten sonra gerekli düzenlemeler yapılmış ve ankete son hali verilmiştir. Anket formunda katılımcıların sosyodemografik özellikleri, 24 saatlik hatırlatma yöntemi, bir günlük besin tüketim kaydı ve besin tüketim sıklığı bilgilerini saptamaya yönelik sorular yer almıştır.

\subsubsection{Besin Tüketim Kaydı}

Katılımcıların enerji ve besin ögesi alımlarını belirlemek için 24 saati hatırlatma yöntemi ile bir günlük besin tüketim kayıtları alınmıştır. Besin tüketim kayıtları bireylerin hafta içine ait tüketim kayıtlarından oluşmuştur. Tüketilen besinlerin ölçülerinin hatasız değerlendirilebilmesi için "Yemek ve Besin Fotoğraf Kataloğu"ndan yararlanılmıştır (31). Tüketilen bazı yemeklerin içine giren malzemelerin ve miktarlarının belirlenmesinde Standart Yemek Tarifeleri kitabından yararlanılmıştır (32). Tüketilen besinlerin enerji ve besin ögeleri içerikleri Beslenme Bilgi Sistemleri (BeBİS) programı ile belirlenmiştir. Katılımcıların enerji ve besin ögesi alımları TÜBER (Türkiye Beslenme Rehberi) (2015)'te yer alan referans alım miktarlarına göre değerlendirilmiștir (33). Günlük aldığg enerji ve besin ögelerinin 65 yaş ve üzeri bireyler için önerilen yeterlilik miktarların belirlenmesinde önerilen değerin altında alanlar $(<\% 67)$ yetersiz, önerilen düzeyde alanlar yeterli (\%67-133) ve önerilen miktarın üzerinde alanlar da (>\%133) fazla olarak kabul edilmiştir (34).

\subsection{Verilerin İstatistiksel Olarak Değerlendirilmesi}

Çalışmadan elde edilen veriler SPSS (Statistical Package for Social Science) istatistik programı ile değerlendirilmiştir. Değişken olarak YBMD hastalığının olup olmaması alınmıştır. Tanımlayıcı veriler için sayı (S) ve yüzde (\%) dağılımı, nitel değişkenler arasında anlamlı bir ilişkinin olup olmadığını belirlemek için Ki-Kare (x2) Anlamlılık Testi uygulanmıştır. Kategorik verilerde örneklem sayısının yetersiz olması sonucu Fisher's Exact Ki-Kare testi uygulanmıştır. Nicel verilerin değerlendirilmesinde dağılımların normallik durumuna bağlı olarak normal dağılım gösteren değişkenlerde Bağımsız Örneklem T-testi, normal dağılım göstermeyen değişkenlerde Mann-Whitney U Analizi uygulanmıştır. Tüm istatistiksel testlerde güven aralığ $\% 95,0$ ve anlamlılık düzeyi $\mathrm{p}<0,05$ olarak kabul edilmiştir. 


\section{Bulgular}

Çalışmaya toplamda 151 birey katılmıştır. Katılımcıların \%62,3'ü erkek, \%37,7'si kadındır. Erkeklerin ortalama yaşı $71,8 \pm 4,7$ yıl, kadınların ortalama yaşı 71,4 $\pm 5,4$ yıldır. Örneklem genelinde katılımcıların \%61,6'sı erken yaşlılık döneminde, \%38,4'ü orta-ileri yaşlılık dönemindedir. Çalışmaya katılan bireylerin \%67,5'i evli, \%31,1'i lise mezunudur. Çalışmaya katılan bireylerin \%61,6'sı sigara kullanmamaktadır (11,8 $\pm 6,4$ adet/gün). Sigara kullanan bireylerin ortalama kullanma süresi $20,4 \pm 11,8$ yıldır. Çalışmaya katılan erkeklerin sadece \%11,7'sinin fiziksel aktivite yapmaktadır; kadınlarda fiziksel aktivite yapan bireye rastlanmamıştır (Tablo 3.1.).

Tablo 3.1. Katılımcıların bazı demografik özelliklerinin dağılımı.

\begin{tabular}{|c|c|c|c|c|c|c|}
\hline & \multicolumn{2}{|c|}{ Erkek } & \multicolumn{2}{|c|}{ Kadm } & \multicolumn{2}{|c|}{ Toplam } \\
\hline & $\mathrm{s}$ & $\%$ & s & $\%$ & s & $\%$ \\
\hline \multicolumn{7}{|l|}{ Yaṣllhk dönemi } \\
\hline Erken Yașl11k (65-74 yas) & 56 & 59.6 & 37 & 64.9 & 93 & 61.6 \\
\hline Onta-fleri Yaslluk (75 yas ve üzeri) & 38 & 40.4 & 20 & 35.1 & 58 & 38.4 \\
\hline \multicolumn{7}{|l|}{ Medeni Durum } \\
\hline Evli & 69 & 73.4 & 33 & 57.9 & 102 & 67.5 \\
\hline Bekar & 25 & 26.6 & 24 & 42.1 & 49 & 32.5 \\
\hline \multicolumn{7}{|l|}{ Sigara Kullanma } \\
\hline Evet & 30 & 31.9 & 9 & 15.8 & 39 & 258 \\
\hline Hayr & 51 & 54.3 & 42 & 73.7 & 93 & 61.6 \\
\hline Braktum & 13 & 13.8 & 6 & 10.5 & 19 & 12.6 \\
\hline \multicolumn{7}{|l|}{ Alkol Kullanma } \\
\hline Evet & 6 & 6.4 & 1 & 1.8 & 7 & 4.6 \\
\hline Hayr & 88 & 93.6 & 56 & 98.2 & 144 & 95.4 \\
\hline \multicolumn{7}{|l|}{ Fizilksel Aktivite } \\
\hline Evet & 11 & 11.7 & - & - & 11 & 7.3 \\
\hline Hayr & 83 & 88.3 & 57 & 100 & 140 & 92.7 \\
\hline Toplam & 94 & 62.3 & 57 & 37.7 & 151 & 100.0 \\
\hline
\end{tabular}

* Kategorik verilerde örneklem sayısının yeterli olduğu değiskenlerde Pearson Ki-Kare testi, yetersiz olduğu değișkenlerde Fisher’s Exact Ki-Kare testi uygulanmıștır.

Çalışmaya katılan YBMD'li bireylerin günlük ortalama enerji alımları $1279,6 \pm 481,3$ kkal'dir. Kontrol grubundaki bireylerin günlük enerji alımı 1381,6 $\pm 552,9$ kkal olup YBMD'li bireylerden daha yüksek bulunmuştur $(\mathrm{p}>0,05)$. YBMD'li bireylerde günlük karbonhidrat, protein ve yağ alımı sirasiyla $145,8 \pm 55,4$ g, 49,3 $\pm 36,4$ g, 53,8 $\pm 26,0$ g'dır $(\mathrm{p}>0,05)$. Benzer şekilde protein ve yağ alımları da YBMD'li erkeklerde (protein 52,3 $\pm 44,5$ g, yağ 55,7 $\pm 28,1 \mathrm{~g}$ ) ortalamanın

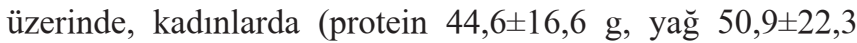
g) ise ortalamanın altındadır $(\mathrm{p}>0,05)$. Her iki grupta ve cinsiyette posa alımı önerilenin altındadır. Çalışmaya katılan bireylerin günlük aldıkları ortalama yağ, posa, omega-3 ve omega-6 miktarları hem cinsiyetler arasinda hem de YBMD ve kontrol grubu arasında istatistiksel olarak anlamlı bir farklılık göstermemektedir ( $p>0,05)$. Alınan günlük ortalama kolesterol alımı ise cinsiyetler arasında anlamlı farklılık gözetmezken, YBMD ve kontrol grubu arasında anlamlı farkl111k göstermektedir( $\mathrm{p}<0,05)$ (Tablo 3.2.).
Tablo 3.2. Bireylerin günlük ortalama enerji, bazı besin ögeleri ve esansiyel yağ asitleri alım miktarları.

\begin{tabular}{|c|c|c|c|c|c|c|c|}
\hline & \multicolumn{2}{|c|}{ Erkek $(\mathrm{X} \pm \mathrm{SS})$} & \multicolumn{2}{|c|}{ Kadun (X未SS) } & \multicolumn{2}{|c|}{ Toplam $(X \pm S S)$} & \multirow{2}{*}{2} \\
\hline & YBMD & KG & YBMD & KG & YBMD & KG & \\
\hline \multicolumn{8}{|c|}{ Makro besin ögeleri } \\
\hline Enerji (kkal) & $1323.1+516.6$ & $1365.8+400.1$ & $1210.6+418.7$ & $1408.7 \pm 754.6$ & $1279.6+481.3$ & $1381.6 \pm 552.9$ & $\begin{array}{l}0.38 \\
0.38 \\
0.22\end{array}$ \\
\hline $\begin{array}{l}\text { Karbonhidrat } \\
\text { (g) }\end{array}$ & $149.7 \pm 55.8$ & $156.1 \pm 565$ & $139.6 \pm 550$ & $129.3 \pm 52.9$ & $145.8+55.4$ & $146.2 \pm 56.44$ & $\begin{array}{l}0.52 \\
0.47 \\
0.92\end{array}$ \\
\hline Protein (g) & $52.3 \pm 44.5$ & $52.0 \pm 204$ & $44.6 \pm 166$ & $68.6 \pm 766$ & $49.3 \pm 364$ & $58.1 \pm 494$ & $\begin{array}{l}0.31 \\
0.58 \\
0.24\end{array}$ \\
\hline Yağ (g) & $55.7 \pm 281$ & $56.3 \pm 244$ & $50.9 \pm 223$ & $66.7 \pm 44.8$ & $53.8=260$ & $60.2 \pm 325$ & $\begin{array}{l}0.88 \\
0.35 \\
0.47\end{array}$ \\
\hline Posa (g) & $14.8 \pm 7.0$ & $17.2 \pm 8.1$ & $13.9 \pm 5.7$ & $16.7 \pm 6.2$ & $14.4 \pm 5.5$ & $17.0 \pm 7.6$ & $\begin{array}{l}0.12 \\
0.31 \\
0.06\end{array}$ \\
\hline Omega-3 (g) & $1.0 \pm 0.7$ & $0.9 \pm 0.5$ & $0.9 \pm 0.8$ & $1.4 \pm 1.1$ & $0.9 \pm 0.7$ & $1.1 \pm 0.8$ & $\begin{array}{l}0.58 \\
0.40 \\
0.34\end{array}$ \\
\hline Omega-6 (g) & $13.5 \pm 7.2$ & $15.3 \pm 8.6$ & $12.6 \pm 10.2$ & $13.3 \pm 7.0$ & $13.1 \pm 8.50$ & $14.5 \pm 8.0$ & $\begin{array}{l}0.35 \\
0.35 \\
0.20\end{array}$ \\
\hline Kolesterol (mg) & $177.8 \pm 168.5$ & $252.9 \pm 2519$ & $169.8 \pm 107.1$ & $288.6 \pm 280.6$ & $174.7 \pm 147.1$ & $266.1 \pm 261.6$ & $\begin{array}{l}0.11 \\
0.15 \\
0.02\end{array}$ \\
\hline
\end{tabular}

* Verilerin normal dağı̆lım gösterdiği değişkenlerde Bağımsız Örneklem T-testi, normal dağı̆lım göstermediği değişkenlerde Mann-Whitney U Analizi uygulanmıștır.

Araştırmada YBMD'si olan yaşlıların A, C, D, E, B6, B12 vitamini ve folik asit ve çinko ve bakır alımları YBMD'si olmayan yaşlılardan daha düşüktür. YBMD'li erkeklerin ise kontrol grubu erkeklerden daha yüksek; YBMD'li kadınların kontrol grubu kadınlardan daha düşük miktarda A vitamini aldıkları belirlenmiştir. Günlük ortalama $\mathrm{C}$ ve $\mathrm{E}$ vitamini alımları da her iki grupta da benzer bulunmuştur. Günlük ortalama C vitamini alımı YBMD'li erkek ve kadınlarda sirasiyla 75,0 $\pm 50,0 \mathrm{mg}$ ve 74,0 $\pm 42,8 \mathrm{mg}$; kontrol grubu erkek ve kadınlarda sırasıly 94,2 $\pm 65,2 \mathrm{mg}$ ve $98,0 \pm 65,2 \mathrm{mg}$ 'dır. E vitamini alımları ise YBMD'li erkek ve kadınlarda sırasıyla $14,5 \pm 7,6 \mathrm{mg}$ ve $13,9 \pm 10,2 \mathrm{mg}$; kontrol grubu erkek ve kadınlarda sırasıyla 16,9 $\pm 9,0 \mathrm{mg}$ ve 14,2 $\pm 5,9$ mg'dır. Günlük ortalama B6, folik asit ve B12 alımlarının örneklem genelinde YBMD'li bireylerde, kontrol grubundaki bireylere kıyasla daha düşük olduğu görülmektedir. Örneklem genelinde YBMD'li bireyler ve kontrol grubunun A, C, E, B6 ve B12 vitaminleri ve karoten ile çinko ve bakır mineralleri alımları arasında istatistiksel olarak anlamlı bir farklılık bulunmazken $(\mathrm{p}>0,05)$, D vitamini ve folik asit alımları arasındaki fark istatistiksel olarak anlamlı bulunmuştur $(\mathrm{p}<0,05)$ (Tablo 3.3.). Çalışmaya katılan YBMD'li erkeklerde yetersiz enerji, karbonhidrat, protein ve posa alanların oranının kontrol grubundan daha yüksek; YBMD'li kadınların ise enerji, karbonhidrat ve protein alımlarının kontrol grubundaki kadınlardan daha düşük olduğu saptanmıştır $(\mathrm{p}>0,05)$ (Tablo 3.4.).

Çalışmaya katılan yaşlılarda C, D, B6 ve B12 vitaminleri ve çinkoyu yetersiz alanların oranı çoğunluğu oluşturmaktadır. Hem kadınlarda hem de erkeklerde A, B6, folik asit, B12 vitaminleri ve bakır minerali yetersizlikleri YBMD'li bireylerde daha yüksek olup, YBMD'li erkeklerde D vitamini, YBMD'li kadınlarda ise C vitamini ve çinko minerali yetersizlikleri kontrol grubundan daha düşük bulunmuştur. 
Çalışmaya katılan YBMD'li bireylerin \%28,0'inde A vitamini, \%50,7'sinde C vitamini, \%12,0'sinde E vitamini, $\% 100,0$ 'ünde D vitamini, \%76,0'sında B6 vitamini, $\% 58,7$ 'sinde folik asit ve $\% 60,0$ 'ında B12 vitamini alımı, \%73,3'ünde çinko, \%44,0'ünde bakır minerali alımı yetersizdir. Tablodan vitamin ve mineralleri önerilenden fazla olanların oranları incelendiğinde, her iki cinsiyette ve örneklem genelinde $\mathrm{A}, \mathrm{C}$ ve $\mathrm{B} 12$ vitaminleri ile bakırı fazla tüketen YBMD'lilerin oranının, kontrol grubundan daha düşük olduğu görülmektedir. Katılımcıların cinsiyeti ve YBMD olma durumu ile folik asit hariç vitamin mineral alımları arasında istatistiksel olarak anlamlı bir fark saptanmamıştır ( $\mathrm{p}>0,05)$ (Tablo 3.5.).

Tablo 3.3. Bireylerin günlük ortalama bazı vitamin ve mineral alım miktarları.

\begin{tabular}{|c|c|c|c|c|c|c|c|}
\hline & \multicolumn{2}{|c|}{ Erkek $(\mathrm{X} \pm \mathrm{SS})$} & \multicolumn{2}{|c|}{ Kadn $(X \pm S S)$} & \multicolumn{2}{|c|}{ Toplam $(\mathrm{X} \pm \mathrm{SS})$} & \multirow{2}{*}{$\mathrm{p}$} \\
\hline & YBMD & KG & YBAD & KG & YBMD & KG & \\
\hline \multicolumn{8}{|l|}{ Vitaminler } \\
\hline $\mathbf{A}(\mathbf{m c g})$ & $834.6 \pm 9983$ & $780.2 \pm 8$ & $896.6 \pm 7127$ & $1239.8 \pm 15152$ & $858.6+893.9$ & $949.5 \pm 1009.6$ & $\begin{array}{l}0.43 \\
0.89 \\
0.57\end{array}$ \\
\hline \begin{tabular}{|l} 
Karoten \\
(mg)
\end{tabular} & $2.6 \pm 2.6$ & $2.6 \pm 1.9$ & $2.1 \pm 1.5$ & $3.2 \pm 3.2$ & $2.4 \pm 2.2$ & $2.8 \pm 2.5$ & $\begin{array}{l}0.73 \\
0.34 \\
0.35\end{array}$ \\
\hline $\mathrm{C}(\mathrm{mg})$ & $75.0 \pm 50.0$ & $94.2 \pm 65.2$ & $74.0 \pm 42.8$ & $98.0 \pm 65.2$ & $74.6 \pm 47.1$ & $95.6 \pm 64.8$ & $\begin{array}{l}.21 \\
0.24 \\
0.24\end{array}$ \\
\hline $\mathrm{E}(\mathbf{m g})$ & $14.5 \pm 7.6$ & $16.9 \pm 9.0$ & $13.9 \pm 10.2$ & $14.2 \pm 5.9$ & $14.3 \pm 8.7$ & $15.9 \pm 8.1$ & $\begin{array}{l}0.23 \\
0.25 \\
0.25\end{array}$ \\
\hline $\mathbf{B}_{12}$ (mcg) & $2.5 \pm 1.6$ & $2.8 \pm 2.2$ & $2.0 \pm 1.3$ & $2.6 \pm 2.5$ & $2.3+1.5$ & $2.8+2.3$ & $\begin{array}{l}0.79 \\
0.59 \\
0.62 \\
\end{array}$ \\
\hline \multicolumn{8}{|l|}{ Mineraller } \\
\hline Çinko (mg) & $6.9 \pm 3.1$ & $7.4 \pm 3.2$ & $6.1 \pm 2.6$ & $7.6 \pm 4.6$ & $6.6 \pm 2.9$ & $7.5 \pm 3.7$ & $\begin{array}{l}0.39^{1} \\
0.48^{2} \\
0.22^{3}\end{array}$ \\
\hline $\begin{array}{l}\text { Bakrr } \\
\text { (mcg) }\end{array}$ & $1.2 \pm 0.7$ & $1.3 \pm 0.5$ & $1.1 \pm 0.4$ & $1.4 \pm 1.0$ & $1.1 \pm 0.6$ & $1.3 \pm 0.8$ & $\begin{array}{l}0.22^{1} \\
0.28^{2} \\
0.12^{3}\end{array}$ \\
\hline
\end{tabular}

* Verilerin normal dağılım gösterdiği değişkenlerde Bağımsız Örneklem T-testi, normal dağı̆lım göstermediği değişkenlerde Mann-Whitney U Analizi uygulanmıştır.

Tablo 3.4. Bireylerin günlük enerji, karbonhidrat, protein ve posa alım miktarlarının referans değerlere göre değerlendirilmesi.

\begin{tabular}{|c|c|c|c|c|c|c|c|c|c|c|c|c|c|}
\hline & \multicolumn{4}{|c|}{ Erkek } & \multicolumn{4}{|c|}{ Kadm } & \multicolumn{4}{|c|}{ Toplam } & \multirow{3}{*}{ p. } \\
\hline & \multicolumn{2}{|c|}{ YBMD } & \multicolumn{2}{|c|}{ KG } & \multicolumn{2}{|c|}{ YBMD } & \multicolumn{2}{|c|}{ KG } & \multicolumn{2}{|c|}{ YBMD } & \multicolumn{2}{|c|}{ KG } & \\
\hline & $\mathrm{s}$ & $\%$ & $\mathrm{~s}$ & $\%$ & $\mathrm{~s}$ & $\%$ & $\mathrm{~s}$ & $\%$ & $\mathrm{~s}$ & $\%$ & $\mathrm{~s}$ & $\%$ & \\
\hline \multicolumn{14}{|l|}{ Enerji } \\
\hline Yetersiz & 16 & 34.8 & 15 & 31.3 & 4 & 13.8 & 8 & 28.6 & 20 & 26.7 & 23 & 30.3 & $0.91^{1}$ \\
\hline Yeterli & 29 & 63.0 & 32 & 66.7 & 21 & 72.4 & 12 & 42.9 & 50 & 66.7 & 44 & 57.9 & $0.07^{2}$ \\
\hline Fazla & 1 & 2.2 & 1 & 2.1 & 4 & 13.8 & 8 & 28.6 & 5 & 6.7 & 9 & 11.8 & $0.42^{3}$ \\
\hline \multicolumn{14}{|c|}{ Karbonhidrat } \\
\hline Yetersiz & 6 & 13.0 & 6 & 12.5 & 5 & 17.2 & 6 & 21.4 & 11 & 14.7 & 12 & 15.8 & $0.76^{1}$ \\
\hline Yeterli & 26 & 56.5 & 24 & 50.0 & 14 & 48.3 & 16 & 57.1 & 40 & 53.3 & 40 & 52.6 & $0.54^{2}$ \\
\hline Fazla & 14 & 30.4 & 18 & 37.5 & 10 & 34.5 & 6 & 21.4 & 24 & 32.0 & 24 & 31.6 & $0.98^{3}$ \\
\hline \multicolumn{14}{|l|}{ Protein } \\
\hline Yetersiz & 16 & 34.8 & 11 & 22.9 & 7 & 24.1 & 11 & 39.3 & 23 & 30.7 & 22 & 28.9 & $0.44^{1}$ \\
\hline Yeterli & 24 & 52.2 & 29 & 60.4 & 18 & 62.1 & 10 & 35.7 & 42 & 56.0 & 39 & 51.3 & $0.13^{2}$ \\
\hline Fazla & 6 & 13.0 & 8 & 16.7 & 4 & 13.8 & 7 & 25.0 & 10 & 13.3 & 15 & 19.7 & $0.56^{3}$ \\
\hline \multicolumn{14}{|l|}{ Posa } \\
\hline Yetersiz & 28 & 60.9 & 25 & 52.1 & 20 & 69.0 & 16 & 57.1 & 48 & 64.0 & 41 & 53.9 & $0.40^{1}$ \\
\hline Yeterli & 18 & 39.1 & 21 & 43.8 & 9 & 31.0 & 12 & 42.9 & 27 & 36.0 & 33 & 43.4 & $0.41^{2}$ \\
\hline Fazla & & & 2 & 4.2 & & & & & & & 2 & 2.7 & $0.22^{3}$ \\
\hline Toplam & 46 & 100.0 & 48 & 100.0 & 29 & 100.0 & 28 & 100.0 & 75 & 100.0 & 76 & 100.0 & \\
\hline
\end{tabular}

* Verilerin normal dağılım gösterdiği değişkenlerde Bağımsız Örneklem T-testi, normal dağılım göstermediği değişkenlerde Mann-Whitney U Analizi uygulanmıştır.
Tablo 3.5. Bireylerin günlük bazı vitamin ve mineral alımlarının referans değerlere göre değerlendirilmesi.

\begin{tabular}{|c|c|c|c|c|c|c|c|c|c|c|c|c|c|}
\hline \multirow{3}{*}{ Vitaminler } & \multicolumn{4}{|c|}{ Erkek } & \multicolumn{4}{|c|}{ Kadm } & \multicolumn{4}{|c|}{ Toplam } & \multirow{3}{*}{ p } \\
\hline & \multicolumn{2}{|c|}{ YBMD } & \multicolumn{2}{|c|}{$\mathrm{KG}^{\mathrm{a}}$} & \multicolumn{2}{|c|}{ YBMD } & \multicolumn{2}{|c|}{$\mathrm{KG}^{*}$} & \multicolumn{2}{|c|}{ YBMD } & \multicolumn{2}{|c|}{$K G^{a}$} & \\
\hline & $\mathrm{s}$ & $\%$ & $\mathrm{~s}$ & $\%$ & $\mathrm{~s}$ & $\%$ & $\mathrm{~s}$ & $\%$ & $\mathrm{~s}$ & $\%$ & $\mathrm{~s}$ & $\%$ & \\
\hline \multicolumn{13}{|l|}{ A vitamini } & \\
\hline Yetersiz & 18 & 39.1 & 13 & 27.1 & 3 & 10.3 & - & - & 21 & 28.0 & 13 & 17.1 & $0.37^{1}$ \\
\hline $\begin{array}{l}\text { Yeterli } \\
\end{array}$ & 19 & 41.3 & 21 & 43.8 & 15 & 51.7 & 17 & 60.7 & 34 & 45.3 & 38 & 50.0 & $0.33^{2}$ \\
\hline Fazla & 9 & 19.6 & 14 & 29.2 & 11 & 37.9 & 11 & 39.3 & 20 & 26.7 & 25 & 32.9 & $0.26^{3}$ \\
\hline \multicolumn{14}{|l|}{ C vitamini } \\
\hline Yetersiz & 28 & 60.9 & 24 & 50.0 & 10 & 34.5 & 10 & 35.7 & 38 & 50.7 & 34 & 44.7 & $0.37^{1}$ \\
\hline Yeterli & 13 & 28.3 & 14 & 29.2 & 17 & 58.6 & 11 & 39.3 & 30 & 40.0 & 25 & 32.9 & $0.14^{2}$ \\
\hline Fazla & 5 & 10.9 & 10 & 20.8 & 2 & 6.9 & 7 & 25.0 & 7 & 9.3 & 17 & 22.4 & $0.08^{3}$ \\
\hline \multicolumn{14}{|l|}{ E vitamini } \\
\hline Yetersiz & 3 & 6.5 & 14 & 29.2 & 6 & 20.7 & 4 & 14.3 & 9 & 12.0 & 18 & 23.7 & $0.01^{1}$ \\
\hline $\begin{array}{l}\text { Yeterli } \\
\end{array}$ & 23 & 50.0 & 15 & 31.3 & 12 & 41.4 & 14 & 50.0 & 35 & 46.7 & 29 & 38.2 & $0.74^{2}$ \\
\hline Fazla & 20 & 43.5 & 19 & 39.6 & 11 & 37.9 & 10 & 35.7 & 31 & 41.3 & 29 & 38.2 & $0.16^{3}$ \\
\hline \multicolumn{14}{|l|}{$\mathbf{B}_{12}$ vitamini } \\
\hline Yetersiz & 24 & 52.2 & 25 & 52.1 & 21 & 72.4 & 18 & 64.3 & 45 & 60.0 & 43 & 56.6 & $0.11^{1}$ \\
\hline Yeterli & 20 & 43.5 & 15 & 31.3 & 7 & 24.1 & 7 & 25.0 & 27 & 36.0 & 22 & 28.9 & $0.54^{2}$ \\
\hline Fazla & 2 & 4.3 & 8 & 16.7 & 1 & 3.4 & 3 & 10.7 & 3 & 4.0 & 11 & 14.5 & $0.07^{5}$ \\
\hline \multicolumn{14}{|l|}{ Mineraller } \\
\hline \multicolumn{14}{|l|}{ Cinko } \\
\hline Yetersiz & 37 & 80.4 & 35 & 72.9 & 18 & 62.1 & 18 & 64.3 & 55 & 73.3 & 53 & 69.7 & $0.72^{1}$ \\
\hline Yeterli & 8 & 17.4 & 12 & 25.0 & 11 & 37.9 & 5 & 17.9 & 19 & 25.3 & 17 & 22.4 & $0.02^{2}$ \\
\hline Fazla & 1 & 2.2 & 1 & 2.1 & - & - & 5 & 17.9 & 1 & 1.3 & 6 & 7.9 & $0.19^{3}$ \\
\hline \multicolumn{14}{|l|}{ Bakır } \\
\hline Yetersiz & 23 & 50.0 & 19 & 39.6 & 10 & 34.5 & 6 & 21.4 & 33 & 44.0 & 25 & 32.9 & $0.39^{1}$ \\
\hline Yeterli & 21 & 45.7 & 24 & 50.0 & 16 & 55.2 & 16 & 57.1 & 37 & 49.3 & 40 & 52.6 & $0.38^{2}$ \\
\hline Fazla & 2 & 4.3 & 5 & 10.4 & 3 & 10.3 & 6 & 21.4 & 5 & 6.7 & 11 & 14.5 & $0.17^{3}$ \\
\hline Toplam & 46 & 100.0 & 48 & 100.0 & 29 & 100.0 & 28 & 100.0 & 75 & 100.0 & 76 & 100.0 & \\
\hline
\end{tabular}

göstermediği değişkenlerde Mann-Whitney U Analizi uygulanmıştır.

\section{Tartışma}

Yaşa bağlı makular dejenerasyon yaşlı insanlarda hem morbidite hem de mortalite açısından yüksek derecede önemli bir risk faktörüdür. Hastalığı etkileyen risk faktörlerine bakıldığında, yaşın en temel risk faktörü olmasının yanı sıra; cinsiyetin, 1rkın, bazı genetik faktörlerin, sigara ve alkol kullanımı ile bazı kronik hastalıkların da önemli risk faktörlerinden olduğu bilinmektedir. Aynı zamanda, bireyin beslenme alışkanlıklarının hastalığın gelişmesinde veya ilerlemesinde etkili olduğu bulunmuştur. Bu nedenle bütün bu risk faktörleri ve hastalığın seyri için pozitif etkileri olduğu bilinen antioksidan vitamin ve minerallerin, ve diğer makro ve mikrobesin ögelerinin tek başına değerlendirilmesi doğru değildir (35-37). Hastalığın oluşumunda temel risk faktörü ileri yaş olarak belirtilirken, retinanın oksijenlenmesinin azalması ve buna katkıda bulunan çevresel faktörlerin birlikte değerlendirilmesi, hastalığın seyri hakkında daha doğru bilgi vermektedir (38-39). Bu nedenle YBMD hastaları üzerinde yapılan çalışmalar birden fazla risk faktörünü birlikte değerlendirmektedir (18,40-41). Tüm bu nedenlerle bu çalışmada risk faktörlerinin tek tek değerlendirilmesinde istatistiksel olarak anlamlı sonuçların çıkmaması beklenilen bir sonuçtur.

Türkiye Beslenme Rehberi’nde (TÜBER) yaşlı bireyler için 
besin çeşitliliğin sağlanması, günde en az üç öğün tüketilmesi, ideal vücut ağırlığı ve kas gücünün korunması, sebze ve meyve tüketiminin artırılması, ekmek ve diğer tahılların yeterli miktarda tüketilmesi, doymuş yağ tüketiminin azaltılması, su ve diğer sıvıların yeterli miktarda tüketilmesi, posa tüketiminin artırılması, tuz ve sodyum tüketiminin azaltılması, şeker tüketiminin azaltılması, alkol ve sigara içilmemesi önerilmektedir. Ek olarak, 60 yaş üstü az aktif erkekler için en az $1867 \mathrm{kkal} /$ gün, kadınlar için $1502 \mathrm{kkal} /$ gün; orta aktif erkekler için 2134 kkal/gün, kadınlar için 1717 kkal/gün enerji, Türkiye ortalama diyetine göre uyarlanmış protein referans aralığına göre erkeklerin 11,9-23,1 g, kadınların 14,0-21,6 g protein, hem erkek hem de kadınlar için en az $130 \mathrm{~g}$ karbonhidrat, hem erkek hem de kadınlar için mümkün olduğu kadar az doymuş yağ ve 250 mg EPA+DHA tüketilmesi gerektiği önerilmektedir. Enerjinin proteinden gelen oranı yaşlı erkek bireylerde \%12-20, kadınlarda $\% 14-20$, karbonhidrattan gelen oranı her iki cinsiyette de \%45-60 ve yağdan gelen oranının her iki cinsiyette de \%20-35 olması gerekmektedir (33). Çalışma sonuçları, TÜBER ile karşılaştırıldığında günlük alınan ortalama enerjinin her iki cinsiyette de yetersiz olduğu belirlenmiştir. Enerjinin karbonhidrattan gelen yüzdesi erkeklerde önerilen sınırlarda iken, kadınlarda önerilenin altındadır. Enerjinin proteinlerden gelen yüzdesi her iki cinsiyette de önerilen sınırlar dahilindedir. Enerjinin yağlardan gelen yüzdesinin her iki cinsiyette de önerilen sinırların üzerinde olduğu görülmektedir. Katılımcıların günlük aldığı enerjinin önerilen sinırlarda olmaması, karbonhidrat tüketiminin önerilen alt sınırlarda olması ve yă̆ tüketiminin önerilenden fazla olmas1, bu bireylerin yeterli ve dengeli beslenmediklerini göstermektedir. Yetersiz enerji alımının malnutrisyona, yüksek yăg tüketiminin kardiyovasküler hastalıklara neden olabileceği unutulmamalıdır.

Besinlerin doğal bileşeni olan posanın yeterli alımının kardiyovasküler hastalıklar, obezite ve diyabet gibi hastalıkların önlenmesinde önemli bir rolü vardır (42). Posanın en iyi kaynakları taze sebze ve meyve, tam tahıl ürünleri ve kurubaklagillerdir. TÜBER'e göre yaşlı bireylerin günlük posa alımlarının her iki cinsiyette de 25 g olması gerekmektedir (33). Çalışmaya katılan erkeklerin günlük aldığı ortalama posa miktarı 16,0土7,6 g, kadınların $15,2 \pm 6,4$ g'dır. Bu verilere göre her iki cinsiyetteki bireylerin posayı yetersiz aldığı görülmektedir. Yetersiz posa alımının gastrointestinal sistem hastalıkları ve bazı kanser türlerinin gelişme riskini artırdığı düşünüldüğünde (43-45) bireyler, yeterli posa alımı konusunda bilinçlendirilmelidir.

Deniz ürünleri ve bitkisel yağların birlikte tüketilmesi diyette hem omega-3 hem de omega-6 yağ asitlerinin bir arada olmasını sağlar (46). Kronik hastalıkların önlenmesinde erkek bireylerin günlük 1,2- 1,6 g/gün, kadınların 0,9- 1,1 g/gün omega-3 almas1, omega-3/omega-6 oranının 1/5-10 (0,10$0,20)$ olması, günlük alınan kolesterol miktarının 300 mg’1 geçmemesi önerilmektedir (47-48).

Yaşlıların beslenme durumunun değerlendirildiği bir çalışmada ise, yaşlıların yaklaşık \%75,0'inin günlük ortalama enerji ve protein alımlarının her iki cinsiyette de alınması gereken miktarın altında olduğu saptanmıştır. Kötü beslenenlerin $\% 77$ 'sinde, malnütrisyonu olanların \%79'unda ve yeterli ve dengeli beslenenlerin \% 74'ünde protein alımının 1,2 g'dan az olduğu saptanmıştır (49).

Yaş ilerledikçe vücut ağırlığının korunması için ihtiyaç duyulan enerji azalmakta, ancak vücut fonksiyonlarının sağlıklı bir şekilde devam ettirilmesi için gereken vitamin ve mineral gereksinimi azalmamaktadır (50). A ve $C$ vitamini gibi antioksidan vitaminlerin yeterli miktarda alınması yaşlılarda mortalite ve çeşitli sağlık sorunları ile doğrudan ilişkilidir (51). Epidemiyolojik ve deneysel çalışmalarda, yaşlılarda sağlığın ve sinir hücrelerinin korunmasında omega-3 yağ asitleri, B grubu vitaminler, C, D ve E vitaminlerinin etkili olduğu belirtilmiştir (52-54). Fakat yaşl1larda yetersiz besin tüketimine de bağl1 olarak yetersiz enerji, vitamin ve mineral alımları gözlenmektedir (55).

TÜBER'de 65 yaş ve üzeri erkek bireylerin $750 \mathrm{mcg}$ A vitamini, $110 \mathrm{mg} \mathrm{C}$ vitamini, $20 \mathrm{mcg} \mathrm{D}$ vitamini, $13 \mathrm{mg} \mathrm{E}$ vitamini, $1,7 \mathrm{mg}$ B6 vitamini, $4 \mathrm{mcg}$ B12 vitamini ve 330 mcg folik asit ile 9,4-16,3 mg çinko, 1,6 mg bakır almaları önerilmektedir. Bu değerler kadınlarda sırasıyla $650 \mathrm{mcg}, 95$ mg, $20 \mathrm{mcg}, 11 \mathrm{mg}, 1,5 \mathrm{mg}, 4 \mathrm{mcg}, 330 \mathrm{mcg}, 7,5-12,7 \mathrm{mg}$ ve 1,3 mg'dır (41). Hastalığın gelişmesinde ve ilerleyişinde risk faktörü olduğu düşünülen bu vitamin ve minerallerin YBMD olan bireylerde daha düşük olması beklenen bir sonuçtur. E vitaminindeki yetersizlik oranının düşük olması, bireylerin yüksek yağlı diyetle beslenmeleri ve yağ tercihi olarak E vitamini ile zenginleştirilen ayçiçek yağı tüketimine bağlı olabilir. Altmış beş yaş üzeri 524 yaşlı bireyle yapılan bir çalışmanın sonucunda katılımcıların \%20,8'inde D vitamini yetersizliği saptanmıştır (56). Benzer şekilde günlük alınan ortalama omega-3 asitleri kontrol grubunda $(1,1 \pm 0,8 \mathrm{~g} /$ gün), YBMD grubundan (0,9 $\pm 0,7 \mathrm{~g} /$ gün) daha yüksek olarak bulunmuştur.

\section{Sonuç}

Yaşa bağlı makular dejenerasyon hastalığ temelde serbest radikaller, serum kolesterolünün yüksek olması ve doku hipoksisi gibi retinal damarları hasara uğratan faktörler ile oluşmakta, retinanın yapısında doğal olarak bulunan lutein, zeaksantin, omega-3 ve omega- 6 yağ asitleri ve antioksidan etkileri bilinen vitamin ve mineral alımı gibi diyetsel faktörler ile de hastalığın seyri değişmektedir. Çalışma sonuçlarının farklılık göstermesinin en temel nedeni hastalığa neden olan faktörlerin tek tek veya birkaç etmenin birlikte değerlendirilmesi ve örneklem sayısının farklılık göstermesi ile ilişkili olabilir. Bu çalışmada da sonuçların istatistiksel açıdan anlamlı olmamasının temel nedeninin yukarıda belirtilen etmenler olduğu düşünülmektedir. $\mathrm{Bu}$ çalışmaya katılan birey sayısının yapılan çalışmalara göre düşük olması, kontrol grubu bireylerinin de herhangi bir göz hastalığına sahip bireyler olması, yaşı bireylerin geriye yönelik beslenme alışkanlıklarındaki ve besin tüketim miktarlarındaki olası hatalar, hastalıkla ilişkili risk faktörleri ile ilgili çoklu analizlerin olmayışı bu çalışmanın sınırlılıklarıdır.

Çalışmaya katılan bireylerin tamamında enerji alımlarında yetersizlik, makrobesin ögesi alımlarının ise yaşlı bireyler 
için önerilen miktarda olmadı̆̆ malnutrisyon belirtileri veya komplikasyonları oluşmadan, yeterli enerji alımı ile dengeli makro-mikrobesin ögesi alımı sağlanmalıdır. Yaşa bağlı makular dejenerasyon hastalarının beslenme durumlarını değerlendiren çalışma sayısı azdır. Bu hastalığa neden olan risk faktörlerin ve diyetsel faktörlerin araştırılacağı uzunlamasına çalışmalara ihtiyaç vardır. $\mathrm{Bu}$ beslenme önerilerinin yanında yapılacak çalışmalara yön vermek adına, bu çalışmanın sınırlılıkları yeterli birey sayısının olmaması, bireylerin birinci derecede akrabalarına ulaşılmaması, çalışma ve kontrol grubunun benzer özellikte olması, bireylerin besin tüketim miktarlarının saptanmasında bir güne bağlı kalınması, bireylerin kan bulgularına ulaşılmamasıdır. Sonuç olarak bu çalışmanın YBMD gelişmiş bireylerde beslenmenin önemi konusunda literatüre önemli

bilgiler sağlayacağı düşünülmektedir.

\section{Kaynakça}

1. Kutsal YG. Neden geriatri. Turk J Phys Med Rehab 2000; 13: 39-42.

2. World Health Organization (WHO). Definition of an older or elderly person Erişim Tarihi: 22 Mayıs 2013. Erişim Adresi: http://www.who.int/healthinfo/survey/ageingdefnolder/en/.

3. Boutayeb A, Boutayeb S. The burden of non communicable diseases in developing countries. Int J Equity Health 2005; 4(1): 2 .

4. Bird AC, Bressler NM, Bressler SB, Chisholm IH, Coscas $\mathrm{G}$, Davis $\mathrm{MD}$, et al. An international classification and grading system for age-related maculopathy and age-related macular degeneration. Surv Ophthalmol 1995; 39(5): 367374.

5. Lim LS, Mitchell P, Seddon JM, Holz FG, Wong TY. Agerelated macular degeneration. Lancet 2012; (379): 17281738 .

6. Haab O. Erkrankungen der macula lutea. Zentralbl Augenheilkd 1885 ;9: 384-391.

7. Gorin MB, Chew E, and Clemons E. Long-term effects of vitamins c, e, beta-carotene and zinc on age-related macular degeneration. AREDS Report No. 35 Ophtha 2013; 12(8): 1604-16111.

8. Merle BM, Silver RE, Rosner B, Seddon JM. Dietary folate, $\mathrm{B}$ vitamins, genetic susceptibility and progression to advanced nonexudative age-related macular degeneration with geographic atrophy: a prospective cohort study. Am J Clin Nutr 2016; 103(4): 1135-1144.

9. Crabb JW, Miyagi M, Gu X, Shandrach K, West K, Sagakuchi AH, et al. Drusen proteome analysis: An approach to the etiology of age-related macular degeneration. PNAS 2002; 99(23): 14682-14687.

10. The Eye Diseases Prevalence Research Group. Prevalence of age-related macular degeneration in the United States. Arch Ophthalmol 2004; 122(4): 564-572.

11. Klein R, Klein BE, Jensen SC, Mares-Perlman JA, Cruickshanks KJ, Palta M. Age-related maculopathy in a multiracial United States population: the national health and nutrition examination survey III. Ophtha 1999; 106(6): 1056-1065.

12. Mitchell P, Smith W, Attebo K, Wang JJ. Pevalence of age-related maculopathy in Australia. the blue mountains eye study. Ophtha 1995; 102(10): 1450-1460.

13. Vingerling JR, Dielemans I, Hofman A, Grobbee DE, Hijmering M, Kramer CF, et al. The prevalence of agerelated maculopathy in the rotterdam study. Ophtha 1995; 102(2): 205-210.

14. Klein R, Klein BE, Jensen SC, Meuer SM. The five-year incidence and progression of age-related maculopathy: the beaver dam eye study. Ophtha 1997; 104(1): 7-21.

15. Klein R, Cruickshanks KJ, Nash, SD, Krantz EM, Nieto FJ, Huang GH, et al. The prevalence of age-related macular degeneration and associated risk factors. JAMA Ophtha 2010; 128(6): 750-758.

16. Saksens NT, Fleckenstein M, Schmitz-Valckenberg S, Holz FG, den Hollander AI, Keunen JE, et al. Macular dystrophies mimicking age-related macular degeneration. Prog Retin Eye Res 2014; 39: 23-57.

17. Vanderbeek BL, Zacks DN, Talwar N, Nan B, Musch DC, Stein JD. Racial differences in age-related macular degeneration rates in the united states: a longitudinal analysis of a managed care network. AJO 2011; 152(2): 273-282.

18. Age-Related Eye Disease Study Research Group. Risk factors for the incidence of advanced age-related macular degeneration in the age-related eye disease study (AREDS). AREDS Report No. 19. Ophtha 2005; 112(4): 533-539.

19. Fraser-Bell S, Wu J, Klein R, Azen SP, Hooper C, Foong AW, et al. Cardiovascular risk factors and age-related macular degeneration: the los angeles latino eye study. Am J Ophthalmol 2008; 145(2): 308-316.

20. Chen X, Rong SS, Xu Q, Tang FY, Liu Y, Gu H, et al. Diabetes mellitus and risk of age-related macular degeneration: a systematic review and meta-analysis,» PloS One 2014; 9(6): e108196.

21. Garcia PM, Marin-Castaño ME. Angiotensin II-related hypertension and eye diseases. WJC 2014; 6(9): 968.

22. Sobrin L, Seddon JM. Nature and nurture- genes and environment- predict onset and progression of macular degeneration. Prog Retin Eye Res 2014; 40: 1-15.

23. Özgür M, Yabancı Ayhan N. Yaşa bağlı makular dejenerasyon ve beslenme. Sağlık Bilimleri Dergisi 2016; 25(3): 161-164.

24. Millen AE, Voland R, Sondel SA, Parekh N, Horst $\mathrm{RL}$, Wallace RB, et al. Vitamin d status and early agerelated macular degeneration in postmenopausal women. Epidemiology 2011; 129(4): 481-489.

25. Christen WG, Schaumberg DA, Glynn RJ, Buring JE. Dietary $\omega$-3 fatty acid and fish intake and incident age-related macular degeneration in women. Arch. Ophthalmol 2011; 129(7): 921-929.

26. Akuffo KO, Nolan JM., Howard AN, Moran R, Stack 
J, Klein R, et al. Sustained supplementation and monitored response with differing carotenoid 16 formulations in early age-related macular degeneration. Eye 2015; 29(7): 902-912.

27. De Velasco PC, Sandre PC, Tavares Do Carmo MG, Faria-Melibeu AC, Campello-Costa P, Ferraz AC, et al. A critical period for omega-3 nutritional supplementation in the development of the rodent visual system. Brain Research 2015; 1615: 106-115.

28. Gorusupudi A, Nelson K, Bernstein PS. The age-related eye disease 2 study: micronutrients in the treatment of macular degeneration. Adv Nutr 2017; 8(1): 40-53.

29. Eisenhauer B, Natoli S, Liew G, Flood VM. Lutein and zeaxanthin - food sources, bioavailability and dietary variety in age-related macular degeneration protection. Nutrients, 2017; 9: 120 .

30. Wu J, Cho E, Giovannucci EL, Rosner BA, Sastry SM, Willett WC, et al. Dietary intakes of eicosapentaenoic acid and docosahexaenoic acid and risk of age-related macular degeneration. Ophtha 2017; 124(5): 634-643.

31. Rakıcıoğlu N, Tek Acar N, Ayaz A, Pekcan G, editörler. Yemek ve Besin Fotograf Katalogu-Ölçü ve Miktarlar, III. Bask1, Ankara, 2012.

32. Merdol TK, editörler. Standart yemek tarifeleri. III.Bask1, Ankara, 2003.

33. TC Sağlık Bakanlı̆̆ı, Pekcan AG, Şanlıer N, Baş M, editörler. Türkiye beslenme rehberi 2015. I.Bask1, Ankara, 2016.

34. Gibson RS. Principles of nutritional assessment. 2nd Edt. New York, Oxford University Press, 2005; p. 324-328.

35. Gopinath B, Liew G, Russell J, Cosatto V, Burlutsky G, Mitchell P. Intake of key micronutrients and food groups in patients with late-stage age-related macular degeneration compared with age-sex-matched controls. Br J Ophthalmol 2016; 101(8): 1027-1031.

36. Munch IC, Toft U, Linneberg A, Larsen M. Precursors of age-related macular degeneration: associations with vitamin $\mathrm{A}$ and interaction with CFHY402H in the eye study. Acta Ophthalmol 2016; 94(7): 657-662.

37. Seddon JM, Silver RE, Rosner B. Response to AREDS supplements according to genetic factors: survival analysis approach using the eye as the unit of analysis. Br J Ophthalmol 2016; 100(12): 1731-1737.

38. McGuinness MB, Karahalios A, Kasza J, Guymer RH, Finger RP, Simpson JA. Survival bias when assessing risk factors for age-related macular degeneration: a tutorial with application to the exposure of smoking. Ophthalmic Epidemiol 2017; 13: 1-10.

39. Srinivasan S, Swaminathan G, Kulothungan V, Raman $\mathrm{R}$, Sharma T. Prevalence and the risk factors for visual impairment in age-related macular degeneration. Eye 2017; 31: 846-855.

40. Chakravarthy U, Wong TY, Fletcher A, Piault E, Evans C, Zlateva $\mathrm{G}$, et al. Clinical risk factors for age-related macular degeneration: a systematic review and meta-analysis. BMC ophthalmology 2010; 10(1): 31-44.

41. Chua J, Lim B, Fenwick EK., Gan AT, Tan AG, Lamoureux E, et al. Prevalence, risk factors, and impact of undiagnosed visually significant cataract: the singapore epidemiology of eye diseases study. PLoS One 2017; 12(1): e0170804.

42. Cho SS, Qi L, Fahey Jr GC, Klurfeld DM. Consumption of cereal fiber, mixtures of whole grains and bran, and whole grains and risk reduction in type 2 diabetes, obesity, and cardiovascular disease. ASN 2013; no. ajcn-067629.

43. Biggelaar LJ, Eussen SJ, Sep SJ, Mari A, Ferrannini E, Dongen $\mathrm{MC}$, et al. Associations of dietary glucose, fructose, and sucrose with $\beta$-cell function, insulin sensitivity, and type 2 diabetes in the maastricht study. Nutrients 2017; 9(4): 380.

44. Krogh K, Chiarioni G, Whitehead W. Management of chronic constipation in adults. United European Gastroenterol J 2017; 5(4): 465-472.

45. Narita S, Inoue M, Saito E, Abe SK, Sawada N, Ishihara $\mathrm{J}$, et al. Dietary fiber intake and risk of breast cancer defined by estrogen and progesterone receptor status: the Japan public health center-based prospective study CCC 2017; 28(6): 569578.

46. Micha R, Khatibzdeh S, Shi P, Fahimi S, Lim S, Andrews $\mathrm{KG}$, et al. Global, regional, and national consumption levels of dietary fats and oils in 1990 and 2010: a systematic analysis including 266 country-specific nutrition surveys. BMJ 2014; 348: g2272.

47. Larsen J, Boeckner L. Omega-3 fatty acids. Erişim Tarihi: 27 Haziran 2006. Erişim Adresi: http://www.ianrpubs.unl. edu/epublic/pages/publicationD.jsp?publication.

48. Baysal A. Beslenme. 15'nci basım, Ankara, Hatipoğlu Yayınları, 2014.

49. Jyväkorpi SK, Pitkälä KH, Pitkälä TM, Björkman MP, Kautiainen H, Strandberg TE, et al. High proportions of older people with normal nutritional status have poor protein intake and low diet quality archives of gerontology and geriatrics. Arch Gerontol Geriatr 2016; 67: 40-45.

50. Van Wymelbeke V, Brondel L, Bon F, MartinPfitzenmeyer I, Manckoundia P. An innovative brioche enriched in protein and energy improves the nutritional status of 19 malnourished nursing home residents compared to oral nutritional supplement and usual breakfast: FARINE+ Project. Clinical Nutrition ESPEN 2016; 15: 93-100.

51. Zhao L-G, Shu X-O, Shu H-L, Zhang W, Gao J, Sun J-W, et al. Dietary antioxidant vitamins intake and mortality: A report from two cohort studies of Chinese adults in Shanghai. Journal of Epidemiology 2017; 27: 89-97.

52. Bourre JM. Effects of nutrients (in food) on the structure and function of the nervous system: update on dietary requirements for brain. Part 1: micronutrients. J Nutr Health Aging 2006; 10(5): 377-385.

53. Cunnane SC, Chouinard-Watkins R, Castellano CA, Barberger-Gateau P. Docosahexaenoic acid homeostasis, brain aging and Alzheimer's disease: can we reconcile the evidence? PLEFA, 2013; 88(1) : 61-70. 
54. Mohajeri MH, Troesch B, Weber P. Inadequate supply of vitamins and DHA in the elderly:Implications for brain aging and Alzheimer-type dementia. Nutrition 2015; 31: 261-275.

55. Bolzetta F, Veronese N, Rui M, Berton L, Toffanello ED, Carraro S, et al. Are the recommended dietary allowances for vitamins appropriate for elderly people. JAND 2015; 115(11): 1789-1797.
56. Jin Y, Xi C, Qin J, Preedy VR, Yong J. Vitamin D and age-related macular degeneration, In Handbook of Nutrition, Diet and the Eye, 2014; 339-348. 